\title{
Pemanfaatan Biochar sebagai Pembawa Rhizobium terhadap Pembentukan Bintil Akar dan Hasil Tanaman Kedelai (Glycine max L. Merril)
}

\section{NI PUTU NENA LUSIANA, ANAK AGUNG NGURAH GEDE SUWASTIKA*), I WAYAN DANA ATMAJA, DAN ANAK AGUNG ISTRI KESUMADEWI}

Program Studi Agroekoteknologi Fakultas Pertanian Universitas Udayana

Jl. PB. Sudirman Denpasar Bali 80231

${ }^{*}$ E-mail: agungsuwastika@yahoo.co.id

\begin{abstract}
The Utilization of Biochar as a Carrier of Rhizobium for the formation of root nodules and Yield of Soybean (Glycine max L. Merril). This study aims to determine the effect of the type of raw materials and particle size of biochar as a Rhizobium carrier on the formation of nodules in soybean plants. This research was conducted from September to November 2020 at the Experimental Station and Laboratory of Soil and Environmental Sciences, Faculty of Agriculture, Udayana University. The research design used was a randomized block design with nested patterns with 2 factorials and 3 replications. The treatment factors consisted of $\mathrm{B}_{1}=$ bamboo biochar, $\mathrm{B}_{2}=$ albasia wood biochar, $\mathrm{B}_{3}=$ corncob biochar, $\mathrm{B}_{4}=$ young coconut skin biochar, $\mathrm{P}_{1}=(0,15-0,50 \mathrm{~mm}), \mathrm{P}_{2}=(>0,50-1,68$ $\mathrm{mm}), \mathrm{P}_{3}=(>1,68-3,36 \mathrm{~mm})$. The parameters observed included effective nodule, nodule size, total bacterial population, ammonium, nitrate, and plant yield. The result of the analysis showed that the type of biochar raw materials had a very significant effect on the parameters of effective nodules, nodules size, total bacterial population and plant yield, but had no significant effect on soil chemical parameters. The treatment of biochar particle size had a very significant effect on the parameters of effective nodules, total bacterial population, and plant yield, and had a significant effect on the size of nodules, but had no significant effect on soil chemical parameters. The conclusion of this study is that the type of raw material for albasia wood biochar is effective as a Rhizobium carrier, which is indicated by the high number of effective nodules, nodules size and total bacterial population of $0,15-1,68 \mathrm{~mm}$ particles.
\end{abstract}

Keywords: Nodules, biochar, Rhizobium, particles size of biochar

\section{PENDAHULUAN}

Biochar adalah bahan organik yang dihasilkan melalui proses pirolisis. Bahan baku biochar berupa limbah pertanian di Indonesia tersedia cukup banyak, diperkirakan mencapai 10,7 ton per tahun, 


\section{NI PUTU NENA LUSIANA et al. Pemanfaatan Biochar sebagai Pembawa Rhizobium...}

yang digunakan sebagai bahan baku biochar diantaranya bambu, kayu albasia, tongkol jagung, dan kulit kelapa muda (Kementerian Pertanian, 2016). Biochar dapat mengikat $\mathrm{CO}_{2}$, sehingga mampu mengurangi konsentrasi $\mathrm{CO}_{2}$ di atmosfer (Sarwono, 2016). Biochar dengan strukturnya yang berpori, dapat menyediakan habitat yang cocok bagi mikroorganisme dan membantu dalam perombakan unsur hara yang akan diserap tanaman (Glodowska, 2014). Menurut Vanek et. al., (2016) biochar dengan diameter pori 0,3 hingga $30 \mu \mathrm{m}$ dapat menjadi habitat yang baik bagi populasi bakteri. Chen et. al. (2017) menyatakan ukuran partikel yang baik bagi habitat mikroba yaitu 80 mesh atau $0,177 \mathrm{~mm}$ (halus), karena partikel biochar halus memiliki ketersediaan nutrisi yang lebih besar daripada partikel kasar. Bahan pembawa yang baik harus tersedia secara lokal, tidak terbatas, tidak mahal, memiliki kapasitas penahanan air yang baik, tidak beracun, ramah lingkungan, mudah diproduksi, disterilkan, ditangani di lapangan, dapat mempertahankan pertumbuhan dan kelangsungan hidup bakteri (Bachtiar et. al., 2019). Jenis bahan biochar yang digunakan dalam penelitian ini adalah bambu (Bambusoideae sp.), kayu albasia (Albizia sp.), tongkol jagung (Zea mays sp.), dan kulit kelapa muda (Cocos nucifera L.), karena bahan tersebut merupakan sumber daya lokal yang tidak digunakan secara optimal, tersedia dalam jumlah melimpah, murah, dan mudah diperoleh. Menurut Nurida (2014). bahan tersebut layak untuk digunakan sebagai bahan pembawa bakteri, seperti bakteri Rhizobium. Bahan baku biochar ini mengandung lignin yang tinggi sehingga dapat mempertahankan senyawa karbon dari senyawa organik agar tidak mudah lapuk. Kandungan lignin pada biochar akan hilang pada proses pembakaran namun akan menghasilkan karbon aktif, yang mengandung mineral seperti kalsium $(\mathrm{Ca})$ atau magnesium (Mg) dan karbon anorganik (Putri et al., 2017).

Mikroba fungsional memiliki peranan penting dalam bidang pertanian. Salah satu mikroba fungsional adalah bakteri Rhizobium, bakteri ini hanya dapat menambat nitrogen jika bersimbiosis dengan tanaman kacang-kacangan (leguminoceae). Salah satu peranan Rhizobium dalam meningkatkan serapan nitrogen dan produksi tanaman kacangkacangan yaitu sebagai pupuk hayati Rhizobium (Satriawan \& Handyanto, 2015). Menurut Tarigan et al. (2021) penambahan 
biochar dalam media tanam pada bibit tanaman sengon laut berpengaruh pada simbiosis rhizobium dengan akar tanaman sengon, hasilnya dapat meningkatkan jumlah bintil (61-75\%) dan bintil akar efetif (527-2381\%) dibandingkan dengan control. Hasil penelitian Purwani \& Sucahyono (2020) menunjukkan bahwa populasi Rhizobium dalam pupuk hayati yang diinokulasi ke dalam bahan pembawa steril lebih dahulu kemudian dikemas menggunakan mesin packaging dengan bahan pembawa biochar+gambut pada masa penyimpanan 6 bulan viabilitas populasi bakteri Rhizobium tertinggi yaitu sebanyak 8,13 log cfu. g-1.

\section{BAHAN DAN METODE}

Penelitian ini dilaksanakan pada bulan September sampai dengan November 2020 di Kebun Percobaan dan Laboratorium Ilmu Tanah Fakultas Pertanian Universitas Udayana.

Alat dan bahan yang digunakan dalam penelitian ini adalah kon tiki, ember besar, ayakan (berukuran $0,15 \mathrm{~mm} ; 0,25$ $\mathrm{mm} ; 0,50 \mathrm{~mm} ; 1,68 \mathrm{~mm} ; 2,00 \mathrm{~mm} ; 2,38$ $\mathrm{mm} ; 2,83 \mathrm{~mm}$; dan 3,36 $\mathrm{mm})$, polibag, termometer gun, alat tulis, tanah steril, inokulan legin, benih kedelai, bambu, kayu albasia, tongkol jagung dan kulit kelapa muda. Penelitian ini menggunakan rancangan acak kelompok pola tersarang 2 faktor, faktor pertama adalah jenis biochar dan faktor kedua adalah ukuran partikel. Faktor perlakuan penelitian terdiri dari $\mathrm{B}_{1}=$ biochar bambu, $\mathrm{B}_{2}=$ biochar kayu, $\mathrm{B}_{3}=$ biochar tongkol jagung, $\mathrm{B}_{4}=$ biochar kulit kelapa muda, $P_{1}=(0,15-0,50 \mathrm{~mm}), P_{2}=$ $(>0,50-1,68 \mathrm{~mm}), P_{3}=(>1,68-3,36 \mathrm{~mm})$. Perlakuan ini diulang 3 kali, sehingga unit penelitian yang dihasilkan sebanyak 36 unit percobaan.

Proses inokulasi dilakukan dengan mencampur masing-masing biochar sebanyak $30 \mathrm{~g}$ ditempatkan dalam gelas plastik kemudian dicampurkan dengan legin kedelai sebanyak $1 \mathrm{~g}$ dan tambahkan air untuk membentuk tekstur bubur. Benih kedelai direndam dengan air gula lalu dimasukkan kedalam bubur pembawa sebanyak 3 sampai dengan 5 biji benih kedelai dan diinkubasi selama tiga hari. Setelah itu masukkan ke dalam polibag yang berisi tanah steril dan dipelihara selama 4 minggu. Pada minggu ke-4 dilakukan pemanenan dan pengamatan bintil akar yang menunjukan bahwa Rhizobium mampu bersimbiosis dengan tanaman kedelai untuk membentuk bintil akar (Glodowska, 2014). 
NI PUTU NENA LUSIANA et al. Pemanfaatan Biochar sebagai Pembawa Rhizobium...

Parameter yang diukur yaitu bintil akar efektif dilihat dari warna merah pada bagian tengah bintil akar ketika dibelah karena mengandung leghemoglobin, ukuran bintil akar, populasi total bakteri (metode plate count), ammonium dan nitrat menggunakan pengekstrak Morgan Wolf dengan spectrophotometer (Balai Penelitian tanah, 2005), berat segar dan berat tanaman kering oven, berat segar dan berat akar tanaman kering oven dengan timbangan digital.

\section{HASIL DAN PEMBAHASAN}

Hasil analisis statistika untuk mengetahui signifikansi pengaruh pemberian jenis dan ukuran partikel biochar terhadap parameter yang diukur disajikan pada Tabel 1. Hasil analisis statistika menunjukkan bahwa perlakuan jenis bahan baku biochar (B) berpengaruh sangat nyata terhadap parameter bintil akar efektif, ukuran bintil akar, populasi total bakteri, dan hasil tanaman, namun berpengaruh tidak nyata terhadap parameter sifat kimia tanah. Perlakuan ukuran partikel biochar $(\mathrm{P})$ berpengaruh sangat nyata terhadap parameter bintil akar efektif, populasi total bakteri, hasil tanaman, dan berpengaruh nyata terhadap parameter ukuran bintil akar, namun berpengaruh tidak nyata terhadap parameter sifat kimia tanah.

Tabel 1. Signifikansi Pengaruh Jenis dan Ukuran Partikel Biochar terhadap Parameter Pengamatan

\begin{tabular}{clcc}
\hline \multirow{2}{*}{ No. } & \multicolumn{1}{c}{ Parameter Pengamatan } & \multicolumn{2}{c}{ Perlakuan } \\
\cline { 3 - 4 } & \multicolumn{1}{c}{ B } & P dalam B \\
\hline 1 & Bintil Akar Efektif (buah) & $* *$ & $* *$ \\
2 & Ukuran Bintil Akar (cm) & $* *$ & $*$ \\
3 & Populasi Total Bakteri $\left(10^{7} \mathrm{spk} \mathrm{g}^{-1}\right.$ tanah) & $\mathrm{ns}$ & $\mathrm{ns}$ \\
4 & Kadar Amonium $(\%)$ & $\mathrm{ns}$ & $\mathrm{ns}$ \\
5 & Kadar Nitrat (\%) & $* *$ & $* *$ \\
6 & Berat Segar Tanaman (g) & $* *$ & $* *$ \\
7 & Berat Kering Oven Tanaman $(\mathrm{g})$ & $* *$ & $* *$ \\
8 & Berat Segar Akar (g) & $* *$ & $* *$ \\
9 & Berat Kering Oven Akar Tanaman $(\mathrm{g})$ & & \\
\hline
\end{tabular}

Keterangan : $* *$ : Berpengaruh sangat nyata
* : Berpengaruh nyata
ns : Berpengaruh tidak nyata 
Agrotrop : Journal on Agriculture Science, 11 (2): 189 - 199 (2021)

Tabel 2. Pengaruh Jenis dan Ukuran Partikel Biochar terhadap Parameter Bintil Akar Efektif, Ukuran Bintil Akar dan Populasi Total Bakteri

\begin{tabular}{|c|c|c|c|c|c|c|}
\hline \multirow{2}{*}{$\begin{array}{l}\text { Perlakuan } \\
\mathrm{B}_{1} \text { pada } \mathrm{P}_{1}\end{array}$} & \multicolumn{2}{|c|}{$\begin{array}{c}\text { Bintil Akar Efektif } \\
\text { (buah) }\end{array}$} & \multicolumn{2}{|c|}{$\begin{array}{c}\text { Ukuran Bintil Akar } \\
(\mathbf{c m})\end{array}$} & \multicolumn{2}{|c|}{$\begin{array}{c}\text { Popolasi Total Bakteri } \\
\left(10^{7} \text { spk }^{-1} \text { tanah }\right)\end{array}$} \\
\hline & 2,33 & $\mathrm{a}$ & 0,32 & $\mathrm{a}$ & 3,59 & \\
\hline $\mathrm{B}_{1}$ pada $\mathrm{P}_{2}$ & 1,67 & $\mathrm{a}$ & 0,28 & $\mathrm{a}$ & 3,42 & \\
\hline $\mathrm{B}_{1}$ pada $\mathrm{P}_{3}$ & 0,00 & $\mathrm{~b}$ & 0,20 & $\mathrm{a}$ & 4,07 & $\mathrm{a}$ \\
\hline $\mathrm{B}_{2}$ pada $\mathrm{P}_{1}$ & 2,33 & $\mathrm{a}$ & 0,33 & $\mathrm{a}$ & 6,06 & \\
\hline $\mathrm{B}_{2}$ pada $\mathrm{P}_{2}$ & 1,33 & $\mathrm{a}$ & 0,42 & $\mathrm{a}$ & 2,00 & b \\
\hline $\mathrm{B}_{2}$ pada $\mathrm{P}_{3}$ & 0,00 & $\mathrm{~b}$ & 0,22 & $\mathrm{~b}$ & 2,97 & b \\
\hline $\mathrm{B}_{3}$ pada $\mathrm{P}_{1}$ & 0,00 & $\mathrm{a}$ & 0,18 & $\mathrm{~b}$ & 0,51 & $\mathrm{a}$ \\
\hline $\mathrm{B}_{3}$ pada $\mathrm{P}_{2}$ & 0,00 & $\mathrm{a}$ & 0,27 & $\mathrm{a}$ & 0,61 & $\mathrm{a}$ \\
\hline $\mathrm{B}_{3}$ pada $\mathrm{P}_{3}$ & 0,00 & $\mathrm{a}$ & 0,35 & $\mathrm{a}$ & 0,41 & $\mathrm{a}$ \\
\hline $\mathrm{B}_{4}$ pada $\mathrm{P}_{1}$ & 2,33 & $\mathrm{a}$ & 0,25 & $\mathrm{a}$ & 3,80 & $\mathrm{a}$ \\
\hline $\mathrm{B}_{4}$ pada $\mathrm{P}_{2}$ & 1,33 & $\mathrm{a}$ & 0,25 & $\mathrm{a}$ & 2,33 & $\mathrm{a}$ \\
\hline $\mathrm{B}_{4}$ pada $\mathrm{P}_{3}$ & 1,00 & $\mathrm{a}$ & 0,37 & $\mathrm{a}$ & 1,83 & $\mathrm{a}$ \\
\hline BNT $5 \%$ & \multicolumn{2}{|c|}{1,46} & \multicolumn{2}{|c|}{0,15} & \multicolumn{2}{|c|}{3,05} \\
\hline
\end{tabular}

Hasil pengukuran dan uji ukuran partikel yang diuji. Jenis bahan baku laboratorium terhadap parameter bintil akar biochar berpengaruh sangat nyata terhadap efektif, ukuran bintil akar dan populasi total ukuran bintil akar. Ukuran partikel biochar bakteri disajikan pada Tabel 2. Data berpengaruh nyata terhadap ukuran bintil signifikansi menunjukkan bahwa jenis akar. Hasil analisis (Tabel 2) menunjukkan bahan baku dan ukuran partikel biochar bahwa $\mathrm{P}_{2}$ pada $\mathrm{B}_{2}$ memberikan hasil terbaik berpengaruh sangat nyata terhadap terhadap parameter ukuran bintil akar yaitu parameter bintil akar efektif. Bintil akar 0,42 cm. Bintil akar efektif dan ukuran efektif hanya terdapat pada $B_{1}$ dan $B_{2}$ bintil akar dalam penelitian ini berkaitan dengan ukuran patikel $\mathrm{P}_{1}$ dan $\mathrm{P}_{2}$ sedangkan dengan adanya aktivitas populasi bakteri. pada $\mathrm{P}_{3}$ tidak terdapat bintil akar efektif dan Bintil akar tidak dapat tumbuh pada akar $\mathrm{B}_{4}$ pada ukuran partikel $\mathrm{P}_{1}, \mathrm{P}_{2}, \mathrm{P}_{3}$, terdapat bintil akar efektif. Perlakuan $\mathrm{B}_{3}$ tidak terdapat bintil akar efektif pada semua tanaman kedelai karena kurangnya hara yang tersedia di dalam tanah dan rendahnya kemampuan jenis bahan baku biochar 


\section{NI PUTU NENA LUSIANA et al. Pemanfaatan Biochar sebagai Pembawa Rhizobium...}

tongkol jagung meretensi hara. Hal ini didukung oleh pernyataan Suryantini (2015) selama proses pembintilan ada dua kondisi yang berkaitan dengan penyediaan unsur hara untuk Rhizobium. Kondisi pertama, terjadi selama fase infeksi ketika Rhizobium terletak di luar sel tanaman. Pada fase ini bakteri secara aktif tumbuh dan membelah diri, dan sepenuhnya tergantung pada ketersediaan unsur hara di luar sel tanaman. Kekurangan hara pada fase ini dapat membatasi terbentuknya bintil akar. Menurut Sa'adah \& Islami, (2019) bintil akar terbentuk disebabkan oleh adanya proses fiksasi $\mathrm{N}$ tanaman dan aktivitas pertumbuhan dari populasi Rhizobium. Bintil akar yang efektif ketika dibelah pada bagian tengah tampak warna kemerahan. Warna merah tersebut disebabkan karena bintil akar terdapat kandungan leghemoglobin dan enzim nitrogenase yang memegang peranan penting pada proses fiksasi $\mathrm{N}_{2}$. Atmaja (2016) menyatakan ukuran bintil akar yang efektif lebih besar dan berpusat pada akar utama, sedangkan yang tidak efektif ukurannya relatif kecil dan tersebar pada cabang akar.

Hasil analisis statistika (Tabel 1) menunjukkan jenis bahan baku dan ukuran biochar berpengaruh sangat nyata terhadap populasi total bakteri. $\mathrm{P}_{1}$ pada $\mathrm{B}_{2}$ memberikan populasi tertinggi yaitu 6,06 $\mathrm{x}$ $10^{7} \mathrm{spk} \mathrm{g}^{-1}$ tanah. Pemberian biochar kayu albasia dengan ukuran partikel 0,15-0,50 mm memiliki luas permukaan yg lebih besar sehingga dapat menjadi habitat mikroba. Hal ini sesuai dengan pernyataan Quilliam et. al., (2013) permukaan biochar kayu albasia sangat berpori, dengan diameter pori umumnya $20 \mu \mathrm{m}$. Luas permukaan yang lebih besar untuk ukuran partikel halus akan meningkatkan aksesibilitas pori-pori dan berpotensi meningkatkan perlindungan bakteri dari predator yang berpotensi menghasilkan peningkatan ketersediaan nutrisi untuk pertumbuhan mikroba. 
Agrotrop : Journal on Agriculture Science, 11 (2): 189 - 199 (2021)

Tabel 3. Pengaruh Jenis dan Ukuran Partikel Biochar terhadap Parameter Sifat Kimia Tanah

\begin{tabular}{|c|c|c|c|}
\hline Perlakuan & Amonium (\%) & Nitrat & $(\%)$ \\
\hline $\mathrm{B}_{1}$ pada $\mathrm{P}_{1}$ & $0,03 \quad \mathrm{a}$ & 0,04 & $\mathrm{a}$ \\
\hline $\mathrm{B}_{1}$ pada $\mathrm{P}_{2}$ & $0,03 \quad \mathrm{a}$ & 0,02 & $\mathrm{a}$ \\
\hline $\mathrm{B}_{1}$ pada $\mathrm{P}_{3}$ & $0,02 \quad \mathrm{a}$ & 0,03 & $\mathrm{a}$ \\
\hline $\mathrm{B}_{2}$ pada $\mathrm{P}_{1}$ & $0,04 \quad a$ & 0,03 & $\mathrm{a}$ \\
\hline $\mathrm{B}_{2}$ pada $\mathrm{P}_{2}$ & $0,03 \quad \mathrm{a}$ & 0,03 & $\mathrm{a}$ \\
\hline $\mathrm{B}_{2}$ pada $\mathrm{P}_{3}$ & $0,03 \quad a$ & 0,02 & $\mathrm{a}$ \\
\hline $\mathrm{B}_{3}$ pada $\mathrm{P}_{1}$ & $0,02 \quad \mathrm{a}$ & 0,02 & $\mathrm{a}$ \\
\hline $\mathrm{B}_{3}$ pada $\mathrm{P}_{2}$ & $0,03 \quad \mathrm{a}$ & 0,03 & $\mathrm{a}$ \\
\hline $\mathrm{B}_{3}$ pada $\mathrm{P}_{3}$ & $0,03 \quad a$ & 0,04 & $\mathrm{a}$ \\
\hline $\mathrm{B}_{4}$ pada $\mathrm{P}_{1}$ & $0,02 \quad a$ & 0,02 & $\mathrm{a}$ \\
\hline $\mathrm{B}_{4}$ pada $\mathrm{P}_{2}$ & $0,02 \quad \mathrm{a}$ & 0,03 & $\mathrm{a}$ \\
\hline $\mathrm{B}_{4}$ pada $\mathrm{P}_{3}$ & $0,03 \quad \mathrm{a}$ & 0,02 & $\mathrm{a}$ \\
\hline
\end{tabular}

BNT 5\%

Hasil analisis statistika menunjukkan jenis bahan baku dan ukuran partikel biochar berpengaruh tidak nyata terhadap parameter sifat kimia tanah. Tabel 3 menunjukkan bahwa kadar amonium tertinggi yaitu $\mathrm{P}_{1}$ pada $\mathrm{B}_{2}$ sebesar 0,04\%. Kadar nitrat yang tertinggi ditunjukkan $\mathrm{B}_{1}$ pada $\mathrm{P}_{1}$ yaitu $0,04 \%$. Kadar amonium di dalam tanah pada biochar kayu albasia dengan ukuran partikel $0,15-0,50 \mathrm{~mm}$ menunjukkan hasil tertinggi, akibat dari pemberian biochar dan penambahan legin sehingga proses metabolisme bakteri berlangsung dengan baik namun kadar amonium di dalam tanah tergolong rendah. Tanaman kedelai dapat mengikat nitrogen
$\left(\mathrm{N}_{2}\right)$ di atmosfer melalui aktivitas bakteri pengikat nitrogen, yaitu Rhizobium. Bakteri ini terbentuk di dalam akar tanaman disebut dengan bintil akar. Keberadaan bakteri Rhizobium di dalam tanah karena adanya pemberian inokulan Rhizobium. Rhizobium menambat $\mathrm{N}_{2}$ dari udara pada 10 hari setelah tanam. Nitrogen di udara $\left(\mathrm{N}_{2}\right)$ diubah menjadi ammonia $\left(\mathrm{NH}_{3}\right)$ melalui proses amonifikasi dan membentuk amonium $\left(\mathrm{NH}_{4}{ }^{+}\right)$yang diserap oleh tanaman. Tanaman memperoleh nitrogen dalam bentuk $\mathrm{NO}_{3}^{-}$karena nitrat mempunyai mobilitas yang tinggi di dalam tanah dan lebih mudah masuk ke akar 
NI PUTU NENA LUSIANA et al. Pemanfaatan Biochar sebagai Pembawa Rhizobium...

tanaman daripada amonium (Maharani,

2008).

Tabel 4. Pengaruh Jenis dan Ukuran Partikel Biochar terhadap Parameter Hasil Tanaman Kedelai

\begin{tabular}{|c|c|c|c|c|c|c|c|c|}
\hline \multirow{2}{*}{$\begin{array}{r}\text { Perlakuan } \\
\mathrm{B}_{1} \text { pada } \mathrm{P}_{1}\end{array}$} & \multicolumn{2}{|c|}{$\begin{array}{l}\text { Berat Segar } \\
\text { Tanaman }(g)\end{array}$} & \multicolumn{2}{|c|}{$\begin{array}{l}\text { Berat Kering } \\
\text { Tanaman }(g)\end{array}$} & \multicolumn{2}{|c|}{$\begin{array}{c}\text { Berat Segar Akar } \\
\text { (g) }\end{array}$} & \multicolumn{2}{|c|}{$\begin{array}{l}\text { Berat Kering } \\
\text { Akar Tanaman } \\
\text { (g) }\end{array}$} \\
\hline & 47,00 & $\mathrm{a}$ & 11,46 & $\mathrm{~b}$ & 14,00 & $\mathrm{a}$ & 1,45 & $\mathrm{a}$ \\
\hline $\mathrm{B}_{1}$ pada $\mathrm{P}_{2}$ & 46,00 & $\mathrm{a}$ & 14,39 & $\mathrm{a}$ & 14,00 & $\mathrm{a}$ & 1,73 & $\mathrm{a}$ \\
\hline $\mathrm{B}_{1}$ pada $\mathrm{P}_{3}$ & 49,00 & $\mathrm{a}$ & 13,08 & $\mathrm{a}$ & 11,00 & $\mathrm{a}$ & 1,30 & b \\
\hline $\mathrm{B}_{2}$ pada $\mathrm{P}_{1}$ & 36,00 & $\mathrm{~b}$ & 12,69 & $\mathrm{~b}$ & 11,33 & $\mathrm{a}$ & 1,13 & $\mathrm{a}$ \\
\hline $\mathrm{B}_{2}$ pada $\mathrm{P}_{2}$ & 61,33 & $\mathrm{a}$ & 16,45 & $\mathrm{a}$ & 10,33 & $\mathrm{a}$ & 1,18 & $\mathrm{a}$ \\
\hline $\mathrm{B}_{2}$ pada $\mathrm{P}_{3}$ & 32,33 & $\mathrm{~b}$ & 8,52 & $\mathrm{c}$ & 9,00 & $\mathrm{a}$ & 0,88 & $\mathrm{~b}$ \\
\hline $\mathrm{B}_{3}$ pada $\mathrm{P}_{1}$ & 31,67 & $\mathrm{~b}$ & 8,58 & $\mathrm{~b}$ & 11,33 & $\mathrm{a}$ & 1,25 & $\mathrm{a}$ \\
\hline $\mathrm{B}_{3}$ pada $\mathrm{P}_{2}$ & 37,00 & $\mathrm{a}$ & 9,50 & $\mathrm{a}$ & 9,00 & $\mathrm{a}$ & 0,84 & $\mathrm{~b}$ \\
\hline $\mathrm{B}_{3}$ pada $\mathrm{P}_{3}$ & 41,33 & $\mathrm{a}$ & 11,05 & $\mathrm{a}$ & 9,00 & $\mathrm{a}$ & 0,76 & $\mathrm{~b}$ \\
\hline $\mathrm{B}_{4}$ pada $\mathrm{P}_{1}$ & 46,33 & $\mathrm{a}$ & 12,71 & $\mathrm{a}$ & 11,00 & $\mathrm{a}$ & 1,14 & $\mathrm{~b}$ \\
\hline $\mathrm{B}_{4}$ pada $\mathrm{P}_{2}$ & 40,00 & $\mathrm{a}$ & 10,38 & $\mathrm{a}$ & 13,00 & $\mathrm{a}$ & 1,56 & $\mathrm{a}$ \\
\hline $\mathrm{B}_{4}$ pada $\mathrm{P}_{3}$ & 41,00 & $\mathrm{a}$ & 10,48 & $\mathrm{a}$ & 10,00 & $\mathrm{a}$ & 1,09 & $\mathrm{~b}$ \\
\hline BNT 5\% & 9,04 & & 2,39 & & 3,30 & & 0,3 & \\
\hline
\end{tabular}

Hasil analisis statistika (Tabel 1) menunjukkan jenis bahan baku dan ukuran partikel biochar berpengaruh sangat nyata terhadap berat segar dan kering oven tanaman. Hasil berat segar tanaman (Tabel 4) menunjukkan bahwa perlakuan jenis biochar (B) terbaik pada $\mathrm{B}_{2}$ dan ukuran partikel (P) terbaik yaitu pada $\mathrm{P}_{2}$ memberikan hasil tertinggi yaitu $61,33 \mathrm{~g}$. Hasil analisis berat kering oven tanaman memberikan hasil tertinggi pada perlakuan jenis biochar (B) terdapat pada perlakuan $\mathrm{B}_{2}$ dengan ukuran partikel $\mathrm{P}_{2}$ yaitu sebesar
16,45 g. Pemberian inokulan Rhizobium mempengaruhi hasil berat segar tanaman dimana inokulan Rhizobium membentuk bintil akar yang dapat membantu penyediaan nitrogen yang dibutuhkan oleh tanaman dalam proses pertumbuhan. Hal ini didukung oleh penelitian Sari et. al., (2015) yang menyatakan bintil akar dapat membantu dalam penyediaan hara $\mathrm{N}$ yang diperlukan oleh tanaman dalam proses pertumbuhan akar, batang, dan daun. Akmal \& Simanjuntak, (2019) menyatakan bahwa tingginya berat segar tanaman 
disebabkan oleh adanya ketersediaan unsur hara dalam tanah yang berkaitan dengan amonium dan nitrat yang cukup di dalam tanah dapat menyebabkan proses fotosintesis berjalan lancar dan asimilat dapat ditranslokasikan keseluruh bagian tanaman.

Hasil analisis statistika menunjukkan jenis dan ukuran partikel biochar berpengaruh sangat nyata terhadap berat segar dan kering oven akar tanaman. Pada Tabel 4 menunjukkan bahwa berat segar akar tertinggi pada jenis biochar (B) terdapat pada $\mathrm{B}_{1}$ dengan ukuran partikel $\mathrm{P}_{1}$ yaitu 14,00 g. Hasil terbaik berat kering oven akar tanaman pada perlakuan B yaitu $\mathrm{B}_{1}$ dengan $\mathrm{P}$ terbaik pada $\mathrm{P}_{2}$ yaitu $1,73 \mathrm{~g}$. Pemberian biochar pada partikel 0,15-0,50 $\mathrm{mm}$ dan inokulan Rhizobium dapat membentuk bintil akar. Jumlah bintil akar yang terbentuk dapat menambah berat dari akar tanaman. Selain itu, akar tanaman dapat berkembang dengan baik akibat pemberian biochar sehingga tanah dapat meretensi air dengan baik. Hal tersebut didukung oleh hasil penelitian Battaglia et. al., (2014) yang menyatakan bahwa pemberian biochar mampu memperbaiki kapasitas tanah merentensi air dan struktur tanah, sehingga akar tanaman lebih mudah berkembang di dalam tanah. Biochar juga mampu memperbaiki aerasi dan porositas tanah sehingga respirasi akar dan kehidupan mikroba lainnya lebih tinggi hal ini ditunjukkan dengan jumlah bintil akar tinggi.

\section{SIMPULAN}

Berdasarkan hasil penelitian dan pembahasan yang diuraikan di atas maka dapat disimpulkan bahwa Biochar kayu albasia efektif sebagai pembawa Rhizobium, ditunjukkan pada jumlah bintil akar efektif, ukuran bintil akar dan populasi total bakteri. Jumlah bintil akar efektif tertinggi terdapat pada partikel $0,15-0,50$ mm yaitu 2,33, ukuran bintil akar dengan hasil tertinggi terdapat pada partikel $>0,50$ - 1,68 mm yaitu $0,42 \mathrm{~cm}$ dan populasi total bakteri tertinggi terdapat pada partikel 0,15 $0,50 \mathrm{~mm}$ sebesar $6,06 \times 10^{7} \mathrm{spk} \mathrm{g}^{-1}$ tanah. Jenis bahan baku dan ukuran partikel biochar berpengaruh sangat bermakna terhadap parameter hasil tanaman. Hasil tanaman terbaik terdapat pada pemberian biochar kayu albasia dengan ukuran partikel >0,50-1,68 mm sebesar 61,33 g dan 16,45 g untuk berat segar dan tanaman kering oven.

\section{UCAPAN TERIMA KASIH}


NI PUTU NENA LUSIANA et al. Pemanfaatan Biochar sebagai Pembawa Rhizobium...

Terima kasih disampaikan kepada Joint Project 2019' 'Bamboo for biochar: an opportunityfor scientific, societal and environmental change in Indonesia (BamBindo)"' yang telah membantu dalam penyiapan materi biochar sehingga penelitian ini dapat berjalan dengan baik.

\section{DAFTAR PUSTAKA}

Akmal, S., \& Simanjuntak, B. H. (2019). Pengaruh Pemberian Biochar terhadap Pertumbuhan dan Hasil Tanaman Sawi Pakchoy (Brassica rapa Subsp. chinensis). Jurnal Ilmu Pertanian, (7)2: 168-174.

Atmaja, I. W. D. (2016). Modul Praktikum Bioteknologi Tanah. Universitas Udayana. 47 hal.

Bachtiar, T., Anas, I., Sutandi, A., \& Ishak. (2019). Perbaikan Kualitas Bahan Pembawa Rhizobium dan Fungi Pelarut Fosfat melalui Sterilisasi Sinar Gamma Co-60 dan Pengaruhnya terhadap Pertumbuhan dan Produksi Kedelai (Glycine max L.). Jurnal Iptek Nuklir Ganendra, 22(1):11-23.

Balai Penelitian Tanah. (2005). Petunjuk Teknis analisis Kimia Tanah, Tanaman, Air, dan Pupuk. Badan Penelitian dan Pengembangan Pertanian. Departemen Pertanian, Bogor.

Battaglia M., Rípodas, C., Clúa, J., Baudin, M., Aguilar, O. M., Niebel, A., Zanetti, M. E., \& Blanco, F. A. (2014). A Nuclear Factor Y Interacting Protein of the GRAS Family Is Required for Nodule Organogenesis, Infection Thread Progression, and Lateral Root
Growth. Plant Physiology, 164: 14301442.

Chen, J., Li, S., Liang, C., Xu, Q., Li, Y., Qin, H., \& Fuhrmann, J. J. (2017). Response of Microbial Community Structure and Function to Short-Term Biochar Amendment in an Intensively Managed Bamboo (Phyllostachys praecox) Plantation Soil: Effect of Particle Size and Addition Rate. Science of the Total Environment, 574: 24-33.

Glodowska, M. (2014). Biochar as A Potential Inoculant Carrier for Plant Beneficial Bacteria. Thesis. Macdonald Campus of McGill University.

Kementerian Pertanian Republik Indonesia. (2016). Biochar. [internet] http://repository.pertanian.go.id/bitstr eam/handle/123456789/6252/Leaflet $\% 20$ Biochar\%203.pdf?sequence $=1 \&$ i sAllowed=y (diakses pada tanggal 09 Desember 2019).

Maharani, P. S. (2008). Nodulasi dan Efektivitas Rhizobium Endogen Tanah Entisol dan Vertisol pada Tanaman Kedelai (Glycine max (L.) Merril). Skripsi. Universitas Islam Negeri Malang.

Nurida, N. L. (2014). Potensi Pemanfaatan Biochar untuk Rehabilitasi Lahan Kering di Indonesia. Jurnal Sumberdaya Lahan Edisi Khusus : 57-68.

Purwani, J \& Sucahyono, D. (2020). Viabilitas Rhizobium dalam Formula Bahan Pembawa dan Cara Inokulasi Dalam Teknik Produksi Pupuk Hayati. Jurnal Agrosain dan Teknologi, 5(2): 99-107.

Putri, V. I., Mukhlis, \& Hidayat, B. (2017). Pemberian Beberapa Jenis Biochar Untuk Memperbaiki Sifat Kimia Tanah Ultisol dan Pertumbuhan Tanaman Jagung. Jurnal 
Agrotrop : Journal on Agriculture Science, 11 (2): 189 - 199 (2021)

Agroekoteknologi FP USU, 5(4): 824- 828.

Quilliam, R. S., Glanville, H. C., Wade, S. C., \& Jones, D. L. (2013). Life in the 'charosphere' - does biochar in agricultural soil provide a significant habitat for microorganisms? Soil Biol. Biochemistry, 65: 287-293.

Rostaliana, P., Prawito, P., \& Turmudi, E. (2012). Pemanfaatan Biochar untuk perbaikan kualitas tanah dengan indikator tanaman jagung hibrida dan padi gogo pada sistem lahan tebang dan bakar. Naturalis-Jurnal penelitian Sumberdaya Alam dan Lingkungan, 1(3).

Sa'adah, N., \& Islami, T.. (2019). Pengaruh Pemberian Macam Biochar dan Pupuk N terhadap Pertumbuhan dan Hasil Tanaman Kedelai (Glycine max L.). Jurnal Produksi Tanaman, 7(11) : 2077-2083.

Sari, R. R. F., Aini, N., \& Setyobudi, L. (2015). Pengaruh Penggunaan Rhizobium dan Penambahan Mulsa Organik Jerami Padi pada Tanaman Kedelai Hitam (Glycine max (L.) Merril.) Varietas Detam 1. Jurnal Produksi Tanaman, 3(8):689-696.

Sarwono, R. (2016). Biochar Sebagai Penyimpan Karbon, Perbaikan Sifat Tanah, dan Mencegah Pemanasan Global: Tinjauan. J. Kim. Terap. Indones., 18(1): 79-90.

Satriawan, B. D., \& Handayanto, E. (2015). Effects of Biochar and Crop Residues Application on Chemical Properties of A Degraded Soil of South Malang, and P Uptake by Maize. Journal of Degraded Andmining Lands, 2(2): $271-281$.

Tarigan, A. A. L. B., Riniarti, M., Prasetia, H., Hidayat, W., Niswati, A., Banuwa, I. S., \& Hasanudin, U. (2021). Pengaruh Biochar pada Simbiosis Rhizobium dan Akar
Sengon Laut (Paraserianthes falcataria) dalam Media Tanam. Journal of People, forest and Enviromental, 1(1)

Vanek, S. J., Thies, J., Wang, B., Hanley, K., \& Lehmann, J. (2016). Pore- Size and Water Activity Effects on Survival of Rhizobium Tropici in Biochar Inoculant Carriers. J Microb Biochem Technol, 8: 296-306. 